maintenant achevé. Il a été placé sous la direction de M. Gaston, Inspecteur Généralde l'Enseignement et de la Jeunesse. Edifiée sur un des meilleurs emplacements de la Cité Universitaire, la Maison de la France d'outre-mer comprend des chambres d'étudiants - I6I à un lit, 42 à deux lits et trois studios réservés à ménages d'étudiants mariés; des salles de travail, un cabinet de lecture, une salle de musique et une salle des fêtes équipée d'une scène. Dans le sous-sol fonctionnent des salles de jeu et un cafetaria. L'administration de la Maison de la France d'outre-mer est soumise aux règles générales appliquées à tous les pavillons de la Cité Universitaire. Chaque maison de la Cité est un centre de vie internationale et un lieu de vie collective. Englobé dans la Cité Universitaire, le pavillon de la France d'outre-mer bénéficiera de tous les avantages qu'accorde la fondation à tous ses résidents.

\title{
Equatoria Projects Scheme: Opening Ceremony at Nzara
}

A sHORT six years ago this place was a dense forest with a narrow red road running through it. Today, the forest has been cleared away and in its place has arisen an industrial town. There is a cotton ginnery, vast spinning and weaving sheds fitted with air conditioning, machinery for crushing cotton seed and extracting the oil, machinery for making soap; there is a power-station and a saw-mill; there are storage sheds and well-fitted workshops for repairs of machinery and mechanical transport; there are water tanks drawing their supply from bores and the nearby river.

Around this industrial centre live the staff who work in it. An attractive park has been laid out and in it the senior staff have their homes. The houses of clerical staff, book-keepers, store-keepers, skilled mechanics, and other artisans are reasonably close to the market, which has a number of well-stocked shops. The unskilled and semi-skilled labourers live close by and around each house they have been given an area in which they or their wives can grow vegetables or other food crops.

Immediately adjacent to the factories is an ample recreation ground which is bordered by a school and a dispensary. Nearby is another large park with buildings near the centre of it. This is a grazing ground and home of a milk herd; a beef herd lives close by. Both of these have to be protected from the tsetse fly and are fed on the by-products of the oil-mill. Dotted about amongst the houses and the parks are small plantations of bananas, pineapples, oranges, tangerines, grapefruits, with mango-trees all over the place.

The Equatoria Projects Board, or E.P.B. as it is more popularly called, was set up in 1946 and was entrusted with the management of production and trading projects in Zandeland and possibly, later, in other parts of the Southern Sudan. The processing of cotton and its by-products was accepted as the economic backbone of the scheme, as cotton has been grown over a period of years in the area around Maridi and it was known that it could be produced over most of Zandeland. As a result, Nzara sprang up containing the factories required to process the cotton and its by-products. As already mentioned, there is a ginnery to separate the lint from the seed. There is a vast factory, first to spin the lint into thread, and then to weave this into cloth. There are going to be dyeing plants to colour the cloth. The oil-mill crushes the oil-seed and produces the oil, some of which goes to yet another factory to help to produce soap while some is refined for sale to local customers; the oil-cake fattens the cattle which help to feed the workers in the factories. There is a power-station, which is the third largest in the country, to create the power with which the factories are run and to provide electric light. It is interesting to note that this power-station runs mainly on charcoal which is produced close to Nzara, the areas which are cut being replanted with quick-growing trees. Cutting and planting will thus follow each other in the same area on a long-term cycle.

In addition to cotton production the Board runs a small plantation at Sakure, about 30 miles from Nzara, for the production of jaggery or brown sugar. This sugar is relished by 
the Azande and the demand for it is increasing. Close to Sakure and at Nzara (and, in the future, at other sites) oil-palm plantations have been planted and these will produce palmoil for helping in soap production and for supply to the Azande for domestic purposes. Production of coffee is also being investigated. The oil-mill will deal with any groundnuts or simsim which may be produced surplus to domestic needs. The dairy herd produces milk for the town, and a beef herd, shortly to be enlarged, produces meat in an otherwise meatless area.

The trading section of the Board has developed side by side with the production section, but over a wider field. Briefly, the functions of this section are to market the products of the Board, and to undertake wholesale and retail trade in other locally produced and imported articles. Its objectives are to develop a true sense of money values in a community which was not used to a money economy and which was liable to exploitation by private traders; to provide useful trade goods of good quality and at low prices; and to train Southern Sudanese traders. Shops have been set up in many districts of Equatoria and Bahr el Ghazal Provinces and many Southern Sudanese have been trained and are being trained as shopkeepers. This section may provide capital for those who have been trained and wish to set up shop, and function as a wholesaler to some of those who have shops.

This then was the setting and background to a simple ceremony held on 8 March at Nzara, to mark the completion of the preliminary stage of construction and the start of industrial production in Zandeland. It is hoped that it marks a new era in Zandeland. Nzara and its factories are a means to an end. They mark the start of economic development and are the bases on which what has been called the Zande Scheme rests. The Zande Scheme aims at the end, which is the social emergence and economic stability of the Azande.

(Sudan News and Features, A. G. McCall)

\section{Belgian Congo: Government Grants for Protestant Schools}

Since 1948 the Protestant Missions in the Belgian Congo have been able, under certain conditions, to receive Government aid for their educational work and in this respect have been placed on an equal footing with the Roman Catholic Missions. Prior to this date only Roman Catholic or 'National' schools were eligible for official inspection, status, and financial and other assistance.

To qualify for official status and Government grants Protestant Missions must first be recommended by the Conseil Protestant du Congo and sign a Government Convention. The teaching staff, European and African, in order to receive State subsidies, must be qualified to teach. To give clear guidance to the missions, Catholic and Protestant, the Government published three brochures in 1948 on L'Organisation de l'Enseignement libre subsidié pour Indigènes avec le concours des societés de missions chrétiennes.

A period of five years was granted to the missions to conform to the new requirements, during which financial and other valuable help has been given to those schools which applied for it and satisfied the Government inspectors. This transition period is likely to be prolonged.

In order to qualify for Government recognition, educational missionaries who are not of Belgian nationality are required to spend at least twelve months in Belgium. They have to know French. They are expected to attend regularly a Belgian 'école normale ou supérieure' for six months and then follow a Colonial Course and pass an examination on the subjects taught. French classes and the Colonial courses are organized by the Colonial Department with the help of excellent professors. Missionaries with a good knowledge of French can obtain exemption from the French classes but not from the examination. Only those who pass the French examination are allowed to take the Colonial Courses. 